\title{
Homelessness as an Incurable Condition? The Medicalization of the Homeless in the Swedish Special Housing Provision
}

\author{
Cecilia Hansen Löfstrand \\ Department of Sociology, University of Gothenburg \\ Sweden
}

\section{Introduction}

In Sweden, the prevailing model for combating homelessness has been, and to a large extent still is, the disciplining staircase model, which stresses absolute sobriety as a criterion for eligibility for municipally organized special housing. The model builds on a view of the homeless as individuals incapable of independent living, albeit ones who are (potentially) able to become capable of independent living and (at least theoretically) of securing an ordinary apartment for themselves on the regular housing market, with the help of discipline and self-regulation (by adhering to the principle of absolute sobriety and complying with a number of other rules). In the staircase model, self-regulation is characteristically seen as a necessary precondition for this gradual improvement in the help receivers' housing standard, their increasing independence (living without rules, regulations, and surveillance), and the stability of their living situation more in general (Sahlin, 2005).

Of the country's population of nine million, approximately 17,800 are homeless, in the latest estimate of the National Board of Health and Welfare (National Board of Health and Welfare [NBHW], 2006). According to the same statistics, 62 percent of the homeless have problems with addiction and 40 percent suffer from a variety of mental disorders. The Board's figures, however, likely fail to accurately capture the size and nature of the homeless problem in the country. Due to respondent selection issues in its survey, there was, for example, no way to adequately assess the number of homeless individuals not suffering from addiction or mental health problems; nor could the number of homeless families be ascertained. Nonetheless, if the results are to be trusted, in 2005 there were 2,620 homeless persons in Gothenburg, Sweden's second largest city, with the municipality becoming singled out as having proportionally speaking the highest number of homeless in the country (54 homeless per 10,000 inhabitants).

In subsequent years, new measures to combat homelessness have been introduced in a number of municipalities in the country. In 2007, for example, the city of Gothenburg officially abandoned the staircase model it had been using until then (see Hansen Löfstrand, 2010), adopting in its stead the so-called Housing First model, as it was named when originally launched in the United States (see Tsemberis et al., 2004). In Gothenburg, the new approach has thus far been limited to a few housing units assigned for the experimentation 
with it. However, even though is the fundamental principle behind the Housing First model is to provide homeless with first-hand apartment contracts, this has thus far not been done in the Gothenburg case; instead, the city has settled into providing what amounts to permanent special housing for the homeless. In effect, what this has meant, as I will argue below, is that instead of marking a genuine shift in the city's homeless policy, the new model has simply been adapted for old purposes: the purpose of finding a way to deal with the problem of "the truly homeless." Who those "truly homeless" are, how they are identified and diagnosed, and what the prognosis is claimed to be is what I will elaborate on in what follows.

More broadly, in this chapter I investigate two concurrent trends in Swedish homelessness policy: the increasing medicalization of the homeless and a shift towards the Housing First approach, with its attendant emphasis on what among the local practitioners is called "symptom tolerance." How should these trends be understood in the particular country context in question, both in isolation and in relation to one another? At first glance, they might seem even contradictory, but, as my analysis will show, they are in fact all mutually related. Indeed, the medicalization of the homeless provided a prerequisite for the consideration of the Housing First model as a possible solution in the first place. However, in the Gothenburg context, the policy recommendations regarding normal housing arrangements based on first-hand apartment contracts that the model implied were taken to simply mean permanent housing arrangements with no expectation of sobriety, sometimes referred to as symptom-tolerance housing, which were based on second-hand rentals. Symptom-tolerance housing or, as it is also called, low-threshold housing has subsequently become a popular solution in the homeless policy of many of the country's larger cities, building on the basic idea that it is necessary to "relinquishing previous demands on people to be drug-free before they are offered housing" (Olsson \& Nordfeldt, 2008, p. 165).

The local adaptations of the Housing First approach in contexts generally prescribing disciplinary measures have thus led to two different models coexisting in parallel. The first of these I call "homelessness as an incurable condition," and it used mostly for homeless deemed incurably ill, or to be suffering from an incurable condition. The goal is to provide permanent special housing and palliative care, which is regarded as a last-resort solution adopted only on account of the perceived failure of medical institutions to accept their responsibility for this group among the homeless: the best solution for it, in this view, would be hospitalization. The second model could be called "homelessness as a curable condition." This model is used for those homeless who are assumed to still be able to develop into capable and independent individuals with the help of regulation and self-regulation applied through the housing staircase model. The goal is for the homeless individuals to ultimately be able to obtain and manage an ordinary apartment of their own, although few actually reach this stage. The reasoning behind the two models goes, respectively, as follows: If suffering from an incurable condition, the homeless individual should be entitled to permanent housing (special housing units for the homeless) even when he or she acts in contravention of the relevant rules (continues to use alcohol, acts violently, threatens others, etc.), for which reason "housing first" is prescribed. If not incurably ill (i.e., still "curable"), the individual has to earn his or her way to housing, by demonstrating ability to comply with the demands of the disciplining staircase system. In other words, when the homelessness of the individual is considered an incurable condition, housing is to be facilitated and "the coercive social control strategies" of the staircase model should be bypassed (Willse, 2010, p. 156). Following Willse, what I will be arguing in what follows is 
that an important precondition for this new initiative was the "invention of chronic homelessness" (Willse, 2010, p. 157).

The research on which this chapter is based was carried out within a broader project entitled "Homelessness as Business: The Marketization of Social Housing in Gothenburg" and funded by the Swedish Council for Working Life and Social Research. The empirical material collected for it thus far consists of transcripts of 36 interviews (with politicians, civil servants, NGO and company representatives, homeless individuals), tenders submitted in the latest two procurement processes for special housing for the homeless, internal documents related to the try-out phase of the municipality's Housing First project, and the returns of a telephone questionnaire distributed to social service offices in the municipality of Gothenburg. For this chapter, I analyzed in depth the interviews with politicians and civil servants responsible for managing the problem on homelessness in the city, along with the interviews with nonprofit and for-profit providers of special housing for the homeless. A central analytical question guiding this analysis was: How is the problem of homelessness and homeless persons - understood and how is the category of "the homeless" constructed and defined among the city's decision-makers and administrators? In addition, recent policy shifts and the planning and implementation of the local Housing First project in the city of Gothenburg were examined investigated. In the sections that follow, I will first review the main arguments put forward by Willse concerning the policy shifts that implementing a Housing First model implies and the possible motives behind it, before presenting my main theoretical framework. The presentation of the research findings then proceeds as follows: I start out by analyzing the views of key politicians and civil servants regarding the issue of homelessness in the city of Gothenburg. After that, I discuss the recently launched Housing First project in Gothenburg (its target group, main features and principles). Finally, I examine the way in which nonprofit and for-profit service providers interpreted and adapted their activities in response to the ongoing changes in the city. The chapter ends with a few concluding remarks on what the policy shift in question has really meant and what likely motivated it.

\section{The Housing First model: The end of medicalization?}

In the US American - just as in the Swedish - context the invention of (chronic) homelessness as a medical problem is connected to the basic idea behind the modern social service agencies, that it is necessary to "work on oneself" in order to gain access to and keep an apartment of one's own:

Medicalization treats housing deprivation as a symptom of personal pathologies that must be cured by experts.... Thus, the medicalization of housing insecurity or deprivation opens a ground for the intervention of disciplinary techniques. (Willse, 2010, p. 165)

The dominant model in combating homelessness has for long consisted of a social worker who "assumes responsibility for guiding the client, or case, through a process of selfevaluation to determinate the individual causes at the root of their problem" (Willse, 2010, p. 165). This process has often involved drug and/or alcohol addiction treatment or comparable. Very frequently, absolute sobriety has thus been made a precondition for eligibility for special housing units for the homeless, in both Sweden (Hansen Löfstrand, 
2010) and in the United States (Willse, 2010). This is described by Willse (2010) as an instance of the medicalization of homelessness. The Housing First approach, Willse (2010, p. 166) suggests, "represents a potential break" from such medicalized models since it involves a "separation of shelter provision from health and social services." Precisely because of this, the model was initially viewed with suspicion by social workers working within a system built on the assumption that health and social services are necessary "for making people 'housing-ready'" (Willse, 2010, p. 166). In a like fashion, the model, upon its introduction, met with skepticism by the local authorities in both Gothenburg and elsewhere in the country. Only recently have there been signs of interest among the country's municipalities in giving the approach a green light.

As Willse (2010, p. 168) has pointed out, to understand the developments in the United States that lead to the shift in focus and the subsequent introduction of the Housing First model, one has to understand "the economic dimension of the invention of chronic homelessness." Some American researchers (Culhane and his colleagues) have successfully argued that, apart from its other positive contributions, the Housing First model is also a more economical way to manage homelessness. At the municipal level where fiscal constraints and budget cuts must frequently be accommodated, the model has indeed come to be viewed as an economically more viable and efficient solution. It is thus the limited economic resources of the municipalities rather than the needs and wants of the individual help-seeking citizens that has to a large extent motivated the policy change (Willse, 2010, pp. 169-172). For many cities and municipalities, the Housing First model has become "the most economically efficient means of managing [the homeless] population" (Willse, 2010, p. 172; emphasis in the original). In this fashion, notes Willse, researchers have been able to "mobilize a neo-liberal discourse on costs and efficiency to advocate successfully what humanist and ethical discourses have failed to do - that people in need of shelter should be housed as quickly as possible," thus by "recasting housing insecurity in terms of financial costs their research provides an economic justification for permanent, long-term housing" (Willse, 2010, p. 171).

In the Swedish context, too, the neoliberal discourse on cost and efficiency has doubtless played a part in influencing the willingness of municipal authorities to try out the model. While a great majority of the Swedish municipalities still adhere to the old model based on disciplining techniques, sobriety, and personal development as prerequisites for eligibility to housing and keeping one's apartment or room, several of them today show a positive attitude towards experimenting with the new Housing First-based model. The main argument used in favor of this policy adjustment has been that the established way of managing homelessness has become too expensive without still bringing the desired results, with the rhetoric remaining silent about the (previously express) goal of reestablishing homeless individuals in the regular housing market or the (hitherto implied) desire to transform deviant individuals into disciplined citizens complying with societal norms, rules, and regulations. Yet, at least in Gothenburg, the willingness to try out the Housing First model has been premised on a more pervasive medicalization of homelessness, rather than bringing about the kind of demedicalization often associated with Housing First initiatives in the research literature.

\section{Theoretical framework}

\subsection{Medicalization}

Medicalization is "a process by which nonmedical problems become defined and treated as medical problems, usually in terms of illnesses and disorders" (Conrad, 1992, p. 209). At the 
same time, the medicalization of a problem does not automatically mean that it has been assigned to the jurisdiction of the medical profession (Conrad, 1992, p. 210). This is made clear in Conrad's own definition of the phenomenon:

Medicalization consists of defining a problem in medical terms, using medical language to describe a problem, adopting a medical framework to understand a problem, or using a medical intervention to "treat" it. This is a sociocultural process that may or may not involve the medical profession, lead to medical social control or medical treatment, or be the result of intentional expansion by the medical profession. (Conrad, 1992, p. 211)

It is important to bear in mind that medicalization of - a medical gaze at - the problem at hand usually does not "fully supplement earlier modes of social control": the medicalization might remain incomplete, competing definitions might exist, or "remnants of previous definition [may] cloud the picture" (Conrad, 1992, p. 218). The coexistence of previous and/or competing definitions will then naturally affect the degree of medicalization itself (Conrad, 1992. p. 220). Furthermore, drawing attention to the process of medicalization, or disclosing instances of medicalization, is not the same as saying that the problem should not be looked at as a medical problem (Conrad, 1992, p. 212). Nevertheless, medicalization may, at least potentially, result in a problem's (such as homelessness) becoming decontextualized and individualized (Conrad, 1992, pp. 223-224), leaving any structural causes overlooked with the result that the responsibility for solving the problem becomes more easily rejected by politicians and civil servants. For this reason, the process whereby deviant behaviors are given medical meanings is always a profoundly political one, one, moreover, that has "real political consequences" (Conrad \& Schneider, 1992, p. 1). In the concluding part of this chapter, I will return to some of such consequences that the process of the medicalization of the homeless brings. It is, however, even at this stage important to bear in mind that what we are discussing here is a very specific version of medicalization: while to some extent the problem of homelessness is defined in medical terms - the "truly" homeless as mentally ill substance abusers suffering from severe functional impairments - what is nonetheless prescribed is care and (in some cases) medication rather than comprehensive treatment. While the "truly" homeless are certainly viewed as needing the kind of treatment that medical professionals working in mental hospitals provide, these institutions are criticized for rejecting what is claimed to be their caring responsibility. Thus, what is actually provided is not a kind of medical intervention that "treats" the problem, that is, one which makes the "truly" homeless housing-ready and capable of independent living in an ordinary apartment, but instead palliative care - easing of the symptoms of an incurable condition and access to a permanent special housing unit meant for the homeless clients of the social services.

\subsection{Diagnosis and prognosis}

As Conrad and Schneider (1992, p. 8) have argued, "the authority to define certain behaviors, persons and things" is the "greatest social control power." This authority belongs to institutions and the people who represent them. In this section, I discuss how the people with this authority, in the Swedish city of Gothenburg, define the problem of homelessness and diagnose homelessness in persons. In this same connection, I will also bring up what the 
politicians and civil servants interviewed for this study stated about what they thought should be done to successfully combat homelessness.

My analysis is inspired by the theoretical concept of framing as first put forth in the work of Erving Goffman and subsequently developed by others. The framing processes can be of many different kinds. In their study of homeless social movement organizations, Cress and Snow (2000), for instance, have made a useful distinction between diagnostic and prognostic frames. Diagnostic frames "shape how the issue is perceived, and identify who or what is culpable," while a prognostic frame "stipulates specific remedies or goals" (Cress \& Snow, 2000, p. 1071). In my analysis in this article, I focus on "accounts of the problem and who or what is to blame (diagnostic framing), and what needs to be done in order to remedy it (prognostic framing)" (Cress \& Snow, 2000, p. 1072). The two types of frames are generally "mutually facilitative," but "prognostic frames might sometimes develop in the absence of articulate diagnostic frames" (Cress \& Snow, 2000, pp. 1099-1100).

The focus on diagnostic and prognostic frames as expressed in accounts means that I look mostly at the way in which claim-makers such as politicians and civil servants construct a condition, in this case homelessness. Loseke (2003, p. 59) has defined diagnostic framing as the activities by which claim-makers "construct a condition as a particular type of condition [while] this, in turn, constructs blame and responsibility." The first step in the analysis of actors' accounts of the problem (who or what is to blame) and what is to be done about it was thus to find out if the diagnostic frame constructed the causes as social - that is, as something having to do with the social structure (the housing market or the welfare system) - or as individual (the behavior, personality, or condition of the unique individual or individuals of this type). According to Loseke (2003, p. 61), successful claim-making strategies ignore the complexity of the issue, relying instead on the construction of simple diagnostic frames.

Social problems are, by definition, "conditions we believe can and should be changed" (Loseke, 2000, p. 97). A central analytical question is therefore: According to claim-makers in the field of homelessness, what should be done in order to combat the problem and who is, explicitly or implicitly, made responsible? Prognostic framing concerns precisely this question:

Prognostic frames [answer] audience members' questions about what should be done. This frame constructs a general line of action (what should be done) and it constructs the responsibility for that action (who should do it). These claims are important because they legitimize some solutions (and not others), they construct some indicators of success (and not others), they assign some people (and not others) the responsibility for changing the condition. (Loseke 2000, p. 98)

\section{Homelessness as an incurable condition}

What made it possible for Swedish politicians and civil servants to at once medicalize the issue of homelessness and introduce (aspects of) the Housing First model into the context of local homelessness work? While, in light of the discussion thus far, it may seem like a contradiction from a more theoretical point of view, for local politicians and civil servants the intensified medicalization of homelessness in fact served as a precondition for the introduction of the Housing First model, or, as we shall see, a certain key aspect of it: permanent (but not regular) housing. 


\subsection{Politicians' position: Homelessness as a psychiatric care problem forced on the municipal special-housing provision}

The driving force behind the medicalization - and I would say, more accurately, the intensified medicalization - of homelessness in the city of Gothenburg was a local politician responsible for the homeless questions in the city government. His own long professional career in psychiatric nursing might have contributed to the new problem construction. In his interview for this study, he stated that for patients experiencing psychoses, it is detrimental to change their daily environment by moving them to another room or apartment:

What I've seen also in my own work [as a psychiatric nurse] is that it may take three, four, five years for a person suffering from a psychosis to adapt to his or her new environment, and then, if you have to move [to another place], the process starts all over again and so on.

The politician's previous knowledge about mental health patients was transmitted onto a from his perspective new group of clients: the homeless. What he held to be true about mental health patients was thereby thought to be true also of the homeless. Taking his previous professional experience as his starting point, and using it as his main frame of reference, the politician therefore decided to recommend the dismantling of the existing housing staircase model, which was built upon the idea of stepwise progression until the achievement of the end goal, an apartment of one's own in the regular housing market. To replace the idea of housing staircase, the politician introduced the metaphor of an elevator: instead of moving through all the steps of the staircase to gradually come closer and closer to the final destination of gaining an apartment of one's own, an individual should take the elevator directly to the correct floor, get off there, and permanently stay there. The longterm strategy he outlined to make all this possible was to turn the city's stock of short-term housing for the homeless into permanent housing units, so as to change the policy of providing temporary accommodation for the homeless.

Another decision the politician made was to initiate collaboration between, on the one hand, the city's social authorities having the responsibility for the local homelessness work and, on the other hand, the local university hospital. This he thought was needed for the necessary outreach programs. During his interview, he stated that "if there is a person who lives in a tent in the woods and does not want any help from us," the first thing to do was "to check that this person does not have any psychiatric problems," something which in his opinion was ideally done through a joint outreach intervention by staff from the local social services and the university hospital. A third decision he took was then to make it the responsibility of the municipality to offer housing to those who were excluded from, or refused by, the city's current special-housing system. The city's stock of special housing units for the homeless had been expanding, but even though a lot of new units were built, "the most difficult cases," or the categories of homeless individuals declared as the official target group of the city's special-housing organization, were still excluded from them (Hansen Löfstrand, 2010; Löfstrand, 2005):

So we were complaining about that, and then we said, "No; everything we build from now on should be for the most difficult cases." And then we got [two new housing 
complexes], you know. And they're specifically for the double-diagnosis cases, the really tough ones, with lots of staff there and so forth.... And then we also hired three nurses to work there to help them with their medication and so on. Because - well, I come from psychiatry, so I know that when a person ends up at a psychiatric ward, after a month or so they feel better, they get their medication and so on, and then they are discharged and sent to the outpatient clinic, then they go there, get a bag of medicines which they will not take, and after two or three months they are just as aggressive again and that's when they are discharged from there and left on their own. So now we employ nurses to deal with this problem.

The strategy that the municipality came to employ - of defining the problem in medical terms, dismantling the housing staircase model, and offering long-term and even permanent special housing to the homeless - did, however, not agree with the requests coming from the municipality's social service offices for access to regular housing for their clients. While the interviewed politician stated that he was "aware of" such requests, he had nevertheless opted not to act on them, continuing instead with the process of further medicalization of the homeless as incurably ill, with the intent of securing more special housing units for the municipality where this category of homeless individuals could live permanently while receiving medical care. While indeed he did much to contribute to the continued medicalization of homelessness, it is true that also his predecessor had focused on those in the wider category of the homeless who are often referred to as double-diagnosis cases, arguing them to be ill but not ill enough to be admitted to the hospitals' psychiatric wards. In the interview excerpt below this politician expresses his frustration with "psychiatry" which, according to him, rejects its responsibility for the "mentally ill people" among the homeless population:

Politician: They are too ill to be managed in ordinary housing, but they are not ill enough for us to have them forcibly hospitalized in a psychiatric ward. The municipality doesn't have any means of coercing them, apart from the cases where somebody is about to die from drug use.... If you are mentally ill and do a little drugs, it's not possible to force anyone.... So here's a group, then, that's not doing well but nobody takes the responsibility for.

Interviewer: But a group nonetheless that has been regarded as a target group for the municipality's own special-housing system?

Politician: Yes, exactly, but they are usually refused or excluded on work environment grounds as they create problems for the staff working there.

To be able to handle this group of homeless individuals more effectively, it was decided to employ staff with previous experience of working within mental health care at some of the special housing units for the city's homeless.

When analyzing the two politicians' accounts about the problem of homelessness, it becomes clear that the diagnostic framing operating in them constructs homelessness as something caused by mental illness that is self-medicated through use of alcohol and drugs, with the diagnostic term used for the condition being "double diagnosis." Nothing is mentioned about other possible causes, such as factors related to the housing market. 
Although the first interviewed politician knew of the local social service offices' express need for something completely different for their clients, their requests for access to ordinary housing in no way featured in his ways of acting on, talking about, or redefining the problem. His case, then, provides an example of the more general tendency to ignore the complexity of the issue in order to construct simple and thus more convincing diagnostic frames (Loseke, 2003, p. 61).

In their accounts about the problem, both of the politicians individualized the problem and presented it as something having to do with illness. One consequence of this way of constructing the homeless as individuals who are ill and suffer from an incurable condition is that they cannot be then held responsible for their homelessness in the manner that other homeless persons are. This, in turn, has enabled the municipality to effect a partial change in its policy: in contrast to the previous situation where the double-diagnosed "most difficult cases" - often referred to as "the truly homeless" - became constantly evicted from different special housing units due to rule breaches, the new policy is to put a stop to the recurrent evictions and offer these individuals permanent special housing. Housing offered by the municipality's special-housing organization is thus regarded as a permanent solution for them (as far as the municipality is concerned). A by-product of the solution is the fact that the homeless individuals benefiting from these new permanent housing arrangements are no longer subject to the kind of disciplining rules and regulations that characterized the housing staircase model. A central concept of the new policy - and something that is required from nonprofit and for-profit providers of social housing for the homeless - is "symptom tolerance": as a provider of special housing for the homeless, one has to tolerate the symptoms of the illness, especially since the illness is regarded as an incurable condition. Furthermore, as evident from the interviews with the above two politicians, public medical services were seen as having the primary responsibility for this category of homeless citizens. Both of the two - and, as we shall see, also the civil servant responsible for the municipality's own special-housing organization - nonetheless claimed that the city's medical services had failed to accept this responsibility by refusing or otherwise excluding these "incurably ill" patients as "not ill enough." This fact, in turn, was then construed as causing the homelessness problem as the two interviewees had come to know it. The problem was thus not construed as a housing problem, but was instead described as a medical care problem. Both the politicians and the high-ranking civil servants interviewed for this research thus effectively claimed the city's medical services to be responsible for both causing and solving the problem, but, since they refused to recognize this responsibility, the municipal special-housing organization was forced to deal with it in practice.

How did it become possible, then, that some version of the Housing First model could be introduced locally? From a purely theoretical point of view, constructing homelessness as an incurable medical condition while simultaneously presenting it as a housing problem seems like a contradiction of terms. As shown by Cress and Snow (2000, pp. 1099-1100), the diagnostic and prognostic frames need not always be "mutually facilitative." From a perspective in which homelessness is regarded as a housing problem, the emergent prognostic frame (access to permanent housing first) does not follow from the diagnostic frame (homelessness as incurable illness), but seems to have evolved rather independently of the latter. One possible interpretation for this is that the "modern" solution provided by 
Housing First, which was vocally advocated in Sweden by (some parts of) the research community, and the criticism that the municipal special-housing organizations were not functioning very well and were costing too much, made it possible to introduce the solution even though it really did not marry well with the prevailing diagnostic frame. As evidenced by the two Gothenburg politicians above, the city's preferred solution was in fact medical treatment and medication, but since the medical services system, according to the perception of the decision-makers, in effect denied its responsibility for those "incurably ill" in the wider homeless population, the next best solution, which was permanent special housing for this category of the homeless, was resorted to instead. This was also presented as the rationale for the new policy of employing mental health care workers as staff at the city's special housing units, and for hiring nurses to pay regular visits and provide medical (somatic) care to the clients at some of the special housing units for the homeless (Sennemark, 2009). In the below quote, an interviewed civil servant in charge of Gothenburg's municipal special-housing organization discusses this new initiative:

The idea is that, since these people rarely come for treatment at our healthcare facilities or in some other way get to receive medical care, we now have a two-year project where we hire three nurses who will work at some of our special housing units, and then we'll follow up on it to see if it makes any difference in these people's lives that they get access to medical care, get their wounds looked after, get to talk to a nurse who might get them to go to a psychiatrist if they need that, or whatever their problem might be.... Then we will review all this and see...if their lives indeed became any better, if their quality of life improved at all.

The first special housing unit in Sweden offering medical care to its homeless clients opened in Stockholm in 2005 (Ingermarson \& Holmdahl, 2010). A few years later, in 2007, medical care to homeless persons staying at special housing units was put on the political agenda also in Gothenburg (Sennemark, 2009). Also the establishment of healthcare centers catering for homeless persons only, in Stockholm in 2001 and in Gothenburg in 2005, provides an example of the medicalization of homelessness, reflecting the tendency to regard homelessness not as a housing issue but as a medical/healthcare problem. The homeless were seen as excluded from the scope of the ordinary healthcare and medical treatment system, which nevertheless was supposed to be equally serving all citizens, or as not really fitting within it well. They were, moreover, considered as needing three different types of medical care: psychiatric care, addiction treatment, and somatic care. The choice to then create separate solutions for the homeless - special housing and special medical care institutions - has, however, only exacerbated their exclusion, as they thereby de facto become treated as almost non-citizens.

What is important to bear in mind is that, in reality, the term "homeless" is a very heterogeneous category. In considering the kind of instances of medicalization of homelessness as described above (homelessness framed as a result of mental illness and selfmedication with alcohol and/or drugs), it needs to be noted that, for instance, those presenting the diagnoses in the above quotes are laymen and not part of the medical establishment. Furthermore, these interviewees had no experience of direct contacts with homeless clients. The street-level bureaucrats at local social welfare offices often propose 
and act on definitions of their homeless clients as either double diagnosis cases or not, at least implicitly in their decisions about where to refer them for placement (to which kind of special housing unit). Like politicians and high-ranking civil servants in general, they lack the medical education ordinarily considered as necessary for performing such diagnoses. It is, moreover, also important to bear in mind that it was primarily politicians and civil servants who contributed to the intensified medicalization of homelessness, in the Gothenburg context at least. As powerful claim-makers, their diagnosis of homelessness as an incurable condition, accompanied by their prescription of special housing where homeless clients can receive palliative care and medication, had a great impact in the policy process. Even though (some of) the street-level bureaucrats claimed that there was a great need for ordinary housing for the homeless clients of the city's social services (and for homeless help-seeking individuals and families refused by the social services as not suffering from any "medical" or "social" problems), the solution put forward was nevertheless permanent special housing for the "truly" homeless, or those suffering from an incurable and irreversible condition and deemed never to be able to live in an apartment of their own in the regular housing market.

\subsection{Civil servants' position: The "truly" homeless as individuals with brain damage, functional disabilities, and a need for permanent special housing}

In her interview, the civil servant responsible for the municipal special-housing organization in Gothenburg connected the problem of homelessness with a contested major reform in psychiatric care that was initiated in Sweden in 1995. The reform, aimed at reducing the number of mentally ill living in large institutions and integrating them more in society, has been widely criticized for leaving mentally ill persons isolated and without proper care. While indeed the proportion of homeless persons regarded as mentally ill has increased since the introduction of the new care policy, no direct correlation has nevertheless been found between the two (Halldin, 2000; NBHW, 1998). All the same, the interviewed civil servant claimed that many of those in the city's homeless population today in the past "used to live in mental institutions." According to her, the psychiatric reform "changed the whole concept of homelessness," because with it, the target group changed so that it now included many more mentally ill homeless. She described the mentally ill as individuals with "functional impairments." Also those in the wider category of the homeless who abuse alcohol were described by her as suffering from such "functional impairments," caused by damage to the brain from prolonged alcohol abuse. These two subcategories were then seen as together constituting the category "the truly homeless" that formed the most important target group for the municipality's special-housing organization. As the interviewee herself described it:

Before, one wasn't even really aware of what long-term alcohol or substance abuse does to the human brain and one's abilities.... Of course, the hard part is the human beings with functional impairments... who also suffer from brain damage. Many of them do.

The interviewee further explained that even though integration into society might serve as a fine ideal, one nevertheless had to face "the reality" - a reality in which the public medical services cannot cope with the homeless addicts, as can neither the psychiatric care services 
nor the wards for somatic care or hospice care. Accordingly, it was the local social services that had to deal with homelessness as a medical care problem:

The fact that they are here [being cared for by the municipal special-housing organization] is because the medical care system cannot manage the integration [of the homeless].... Have you ever seen a double-diagnosed homeless person at a local healthcare center?

Just like the politician responsible for homelessness in the Gothenburg municipality, the interviewed civil servant in charge of the municipality's special-housing organization pointed to the recent changes in the local policy that brought an emphasis on permanent placement at special housing units. Initially, she interpreted this political will as a will to offer the homeless more or less ordinary apartments, albeit within the framework of the municipal special-housing organization (without first-hand contracts and normal lease terms). In her understanding, the need for "ordinary housing" had meant "ordinary apartments," at least when it came to their material standard:

When I started out here [in the municipal special-housing organization], I thought: "We have to refashion [one of the special Gothenburg housing units] into fully adequate apartments and then people may stay on." For precisely this group of people with early disturbances - those who are violent, those who look for conflicts, who brawl and fight at the social service offices and are refused admission.... And then, instead, we'd be like: "Here you've got your key, now you have your apartment, you can do whatever you want, here you may live, you can take care of yourself here...you never need to move" - things like that, you know.

The interviewee then went on to describe a process of gradual realization and increasing comprehension, a process leading her to understand that there nonetheless were some people - those in the homeless population who can be categorized as suffering from an incurable illness - who should not be placed in regular-type housing. She could not view an apartment in the regular housing market through a first-hand contract as a good solution or even an appropriate end goal for the process of integration into society, because "integration will never be possible." On the other hand, according to the interviewee, this category of the homeless should not be placed in housing units either where, due to predictable rule breaches, they were liable to be moved to another special housing unit "every other night." Accordingly, permanent special housing for the homeless, instead of permanent regular housing first, became the preferred political model to combat long-term homelessness in the municipality. The interviewed civil servant claimed this kind of homeless to be unable to live in ordinary apartments:

We cannot heal people just because we're the municipal special-housing organization.... Sometimes people in general don't realize what kind of functional impairments there actually are out there...because they have never in their entire lives made a cup of coffee or boiled an egg or even a kettle of water. You don't think that there are that types of functional impairments.... But they can stay there in any case, we 
say, as long as they want. We don't think that...the pathway out of homelessness is an apartment of one's own.

In consequence, some of the city's housing units that had previously functioned as shortterm shelters were converted into long-term special housing units. Today, these units are to offer a permanent solution for those homeless diagnosed as suffering from an incurable condition. This policy shift was described by the interviewed civil servant as a result of a learning process in which she, too, initially thought that everyone should have their own apartment "with a kitchen and all that." However, her new colleagues with a long experience in homelessness work had made her revise her initial thinking that subsequently appeared almost naïve:

Then they started telling me, "But have you thought about this, that it might not be that they might not be able to enjoy it; on the contrary, it might prove an obstacle to their coping." So we gave up on the idea of providing them with regular, fully functioning apartments. We could be wrong, too, of course - I don't know. But that's the way we do it, anyhow.

Another interviewed civil servant, who at the time of the interviews was responsible for coordinating the outreach work carried out by the municipality in collaboration with certain nongovernmental church-based organizations, explained that many of the homeless individuals encountered by the outreach staff had been refused admittance to the special housing units "because they threaten the staff or other people staying there, which is actually very common." In fact, a list of barred persons had been created at the unit where the interviewee worked, which was maintained by the municipality and offered shelter-like temporary accommodation. Contrasting with these individuals, there was "a group of people who land in [name of the housing unit] and don't have social problems" and thus did not end up on the list of barred persons. The interviewee differentiated this latter category of "the houseless" from "the homeless," who were "barred" not only from the regular housing market but also from most units within the city's special-housing sphere (Löfstrand, 2005). She described "the homeless" as individuals with mental disabilities who proved a challenge for the organization to handle: they were often "people who come in here with guns.... It's not all that easy [to deal with them as] the staff are human beings, too." Just as the politicians and the civil servant quoted above, also this civil servant depicted "the truly homeless" as mentally ill. The interviewee further claimed the general public to think that "nobody cares" about this group of homeless persons; this was an illusion, however, since:

these are persons we have worked with for many years already, basically trying to lure them into the van [used in the outreach work] just so that they would come with us and not be harmed, and drive them to hospital.

"The truly homeless" thus suffered from an illness, and homelessness was portrayed as an incurable condition, impossible for the local social services authorities to manage. The "truly homeless" were, moreover, in need of medical treatment and healthcare, not ordinary 
housing. The city's longstanding special-housing organization, based on a disciplinary model where access to housing required both regulation by others and self-regulation, had thus not been replaced by a Housing First model based on the idea that regular housing (including first-hand apartment contracts) provided a necessary precondition for the ability to handle all other possible problems (economical, medical, mental, or addiction problems). What thus happened when the new trend - the Housing First model - was interpreted within this specific local professional culture, becoming used for its own particular ends, was that only some of its aspects were incorporated into the framework of the local specialhousing organization. A catchword used in the debates around the new model was permanent housing for the homeless. This suited the municipal politicians and civil servants who wanted to put an end to the endless movement of the homeless between shelter-like special housing and sleeping in the rough. Correspondingly, it became possible for the municipality to introduce special housing as a permanent solution for the homeless (as well as for the municipality). In this way, the in reality rather old solution (special housing for the homeless with "symptom tolerance," which had been the norm for long until the period of the preceding staircase model commenced in the 1980s) could thus be made to appear as something modern, simply by refashioning it in terms of the latest trend - the Housing First model. This way of on the surface adapting to the latest trend while in reality still following the old model has been described as path dependence, in which previous choices affect which decisions will be taken in the future, with the path already taken rendering some choices and decisions seemingly unthinkable while leaving others appear only natural (Pierson, 2000). The local interpretation of the Housing First approach deviated from the original model in at least one important aspect: while a first-hand apartment contract with normal terms of occupancy formed the most important aspect of the new model, the same starting point did not inform the local interpretation and adaptation of it. Since, as it was perceived, the medical service and healthcare system rejected its responsibility for "the truly homeless" (the homeless who are mentally ill or addicts or have brain damage) suffering from an incurable condition marked by functional impairments, permanent special housing was introduced as a solution to serve both these individuals and the municipality itself. It remains to be seen if, with the new hybrid model in place, the endless evictions for rule breaches will cease and, to the extent that happens, what kind of sanctions might remain for the city's special-housing agency to use for its purposes, since the principle is now that the homeless individual is to be allowed to stay on permanently even when he or she "misbehaves" by acting in contravention to the agency's rules.

\subsection{The Housing First model translated}

In fall 2010, the local social service authorities in Gothenburg started planning for a new project openly influenced by the Housing First model as originally developed in United States. The model had been advocated by Swedish researchers working on homelessness issues, especially at Lund University where the Housing First model was heavily promoted as the best choice for Swedish municipalities. According to some of the key figures working at the university (Heule et al., 2010), the basic principles relied on by the model are the following: (1) Homelessness should first and foremost be considered as a housing problem; (2) homeless persons should be reestablished in the regular housing market as quickly as possible; (3) access to housing of one's own forms an important precondition for 
subsequently solving other problems; (4) permanent and safe housing is to be considered a basic human right that belongs to everyone. The authors recommend that these basic features be incorporated into local homelessness work in general, with the long-term goal of integrating them into the municipal special-housing organizations and their overall operation as their constitutive principles. As important preconditions for its successful implementation, it is generally considered that the model depends on access to ordinary housing through first-hand rental contracts, that the support offered through it should always be optional, and that the homeless should be allowed to stay in their apartments permanently. In addition, any social and geographical segregation is to be avoided by incorporating the apartments offered to homeless persons into the city's ordinary rental housing stock (and not confined to separate apartment buildings for the homeless clients of the social services). To facilitate the achievement of these goals, Lund University offers the municipalities willing to try out the model a range of education and evaluation services, along with access to research on the topic (see http://www.soch.lu.se/o.o.i.s/21367). Some of the Swedish municipalities have, as a result, expressed interest in giving the model a try. The factors behind their reasoning often relate to the high cost of their current programs to combat homelessness and the persistence of the problem of homeless individuals sleeping in the rough. While the city of Gothenburg is among the municipalities not receiving guidance from the researchers at Lund University, its approach is nevertheless very much inspired by the Housing First model as promoted at Lund University and by US American researchers such as Tsemberis and his colleagues.

In a manner much like in the municipalities acting in direct collaboration with Lund University, in 2010 politicians and civil servants from Gothenburg's municipal specialhousing organization issued a statement to the effect that the city was going to try out the Housing First model, by launching a small-scale project in which a few apartments were to be acquired for the purpose of offering direct access to independent housing to homeless individuals thus far excluded from the city's special-housing services as too "difficult" to manage within their framework. There was one major difference, however: the homeless clients were not to be offered first-hand apartment contracts, not in Gothenburg nor in any other municipality trying out the model. In Gothenburg, the civil servants responsible for homelessness were well aware that this meant significant deviation from the original model. The method was, consequently, interpreted as being all about housing as the first intervention and a foundation:

In its original and orthodox form [the model] means first-hand apartment contracts, issued directly and without any intermediaries or conditions other than those stipulated in the Rental Act. Most of those who adopt the approach are not very "orthodox" in every respect, however. [In many municipalities] the possibility offered to the homeless comes with additional terms and limiting conditions or initially issued second-hand rental contracts. (City of Gothenburg, 2011, p. 1)

The Housing First project in Gothenburg was named "Housing as a Foundation," and it was launched when an opportunity for it arose with one of the city's a special-housing units scheduled for closing towards the end of 2010. The facilities involved, consisting of sixteen individual apartments in one building and an additional nine apartments spread out in the 
area, were then adopted for use in the Housing First project. The apartments were rented by the local social authorities and then sublet to these authorities' homeless clients; in other words, the local social services signed the first-hand contracts, with their clients then entering into second-hand contracts with the social services. No additional terms and conditions for occupancy were included other than those enumerated in the country's Rental Act that apply to all tenants in the regular rental market. The formerly homeless clients occupying the apartments were considered to need support in their everyday life (to make sure they paid rent, did not disturb their neighbors, took care of their apartments), and the involvement of medical care and addiction care institutions was considered necessary (City of Gothenburg, 2011).

The local adaption of the Housing First model to combat homelessness in the form of the this project was presented as a way to solve an urgent and long-standing problem: the exclusion of certain categories of homeless individuals not only from the regular housing market, but also from the city's special-housing sphere consisting of all the beds, rooms, and apartments offered to the homeless clients of the city's social services and run by different actors (municipal, nonprofit, and for-profit) (see Löfstrand, 2005). The task at hand was to provide housing for a small group of homeless persons who were regarded as exceptionally hard to handle for all the practitioners and authorities involved (Holm, n.d.). The size of the target group in the municipality is described as "fairly limited," estimated at 15 to 30 persons. These are described as individuals whose behavior (as either violent or otherwise excessively unpleasant) has made them unsuited for living together with others in ordinary conditions. They are, furthermore, described as mostly men who are well known to the city's social service offices, nongovernmental organizations, and medical care institutions. The support to these individuals was to be organized in line with the "case management model," in that all authorities in contact with homeless individuals were to gather together in working groups so as to coordinate their efforts in a more efficient manner and that way help facilitate and enhance the support work and possible interventions. The groups meet regularly and share the responsibility for the clients in question (Holm, n.d.). The approach adopted by the municipality thus clearly mixes elements of the Housing First model with disciplinary interventions associated with the hitherto dominant housing staircase model.

\subsection{The adaptation of nonprofit and for-profit housing providers to the "new" politics of "symptom tolerance"}

In keeping with the prevailing policy as practiced until now, the municipality, nonprofit organizations, and (to a lesser extent) private companies had been evicting special-housing residents on the grounds that they had appeared at their housing units under the influence of alcohol or consumed alcohol on premises. The new policy, however, clearly stated that the actors involved - whether municipal, nonprofit, or for profit - were to provide longterm special housing without the ability to consider relapses as grounds for eviction. The housing providers are to explicitly describe how they "work with symptom tolerance." As noted above, among the municipal authorities the "truly homeless" are regarded as suffering from an incurable condition. The new catchword of "symptom tolerance" then fit very well with the manner homelessness was defined in medical terms: the symptoms of an incurable condition (such as incapacity to abstain from alcohol and/or drugs) had to be tolerated. In consequence, the non-municipal providers of special housing (both nonprofit 
and for-profit ones) therefore had to adapt their practices to the new policy, introduced to put an end to the endless circulation of "the truly homeless" between shelter-like housing units and sleeping in the rough. In response to the question of what sort of providers (among the nonprofit and for-profit ones) the municipality should contract for its initiative, the interviewed civil servant responsible for the city's special-housing organization explained that, contrasting with the earlier situation, the effect of the new policy was that:

[The providers of special housing for the homeless] can no longer come in here and just offer housing where everybody's required to stay sober; we also need housing where...[the principle of] symptom tolerance is observed. But even then you can still say that boozing is not allowed here. They can't do that at [the municipality's own special-housing units], either. You can come home when you are drunk, but you can't have a drinking party in your apartment or on premises, to put it that way. You can't do that at our own units, either. But then [the providers] have to explain to us how they work with symptom tolerance, how they deal with relapse cases.

In a focus group interview with nonprofit providers of special housing for the homeless, these providers linked what they termed "the new municipal strategy" to "symptom tolerance," which was described as "the dominant term everywhere right now" and as "a key phrase." To more effectively pursue its goal of minimizing the constant drift between temporary accommodation and sleeping in the rough among the city's more problematic homeless population, the municipality made a decision to give precedence in the official procurement process to providers who offered special housing where the principle of symptom tolerance would be followed. Organizations that for one reason or another are unable to provide "symptom tolerance housing" have in consequence had hard time surviving. Indeed, the nonprofit providers often understood the new policy to imply that the clients could "have relapses a hundred times over and still be able to stay on [in their apartments]," which made the new policy unpopular and difficult to implement in their eyes, as, over the years, they had slowly but steadily just managed to adapt to the previous policy of drug-free units and absolute sobriety as preconditions for housing. According to the interviewed nonprofit providers, the central message from the politicians to the civil servants and actors involved in the provision of special housing for the homeless was: "As little people as possible on the city streets." The interviewees criticized what they saw as the new official view of the municipality: that there are "hopeless cases" unable to "escape their situation" (which for them meant "unable to overcome their addiction"). This was regarded as something that only contributed to cementing the marginalized situation of certain categories of the homeless, leaving them permanently outside of the regular housing market and society. According to the nonprofit providers, the municipality construed "the truly homeless" as ill individuals who were fundamentally "incurable" and thus represented what amounted to hopeless cases: "Addicts who have been taking heroin for five, six years are incurable.... They have this idea that these people, they have to live with their symptoms, this illness; it's more and more about that sort of thinking."

Although the new policy has resulted in fewer homeless people on the streets of the city center, it has at the same time become even more difficult for those among the homeless population who are categorized as "truly homeless" to reestablish themselves in the regular 
housing market or even gain access to self-contained "reference apartments" in the city's special housing units, which in the prevailing system provide a chance for them to prove their readiness for and practice independent living. As noted above, the politician in charge of the problem of homelessness issues in the Gothenburg city council had received signals from the municipality's local social service offices that what was really needed for their homeless clients was apartments integrated into the regular rental market. The interviewed nonprofit providers of special housing judged the need in the same way: "There are far too few [of such] apartments; they [the homeless residents of special housing units] cannot advance, they will only get stuck."

Regardless of what was requested from them, then, the politicians and civil servants in charge of homelessness in the municipality have continued to develop local homelessness policy in just the opposite direction. To be sure, this has happened, to some extent at least, as a result of a feeling that their hands are tied, given their basic inability to provide regular apartments due to a general housing shortage and the current housing market situation in the city, the reluctance of local landlords, and other similar factors curtailing their leverage. At the very minimum, however, the politicians in charge should, at least in theory, be able to influence the rental policy of the municipal housing companies. To a significant extent, the current shift in policy has thus come about a result of the more or less conscious construction of "the truly homeless" who are diagnosed as suffering from an incurable condition. The prognosis for them reads as follows: housed permanently in municipally provided special housing units or in units provided by other actors providing symptomtolerant special housing, they will never gain access to an apartment of their own in the regular housing market.

\section{Conclusion}

The "new" politics of "symptom tolerance" and (more or less) permanent special housing for the homeless as a way of combating long-term homeless in the city of Gothenburg very much resembles an earlier model followed by the municipality up until the end of the 1980s: the hostel system. The one notable exception is that during the earlier period, the "symptoms" of the incurable condition could be, and also were, "tolerated" at hostels that provided no more than temporary accommodation for the homeless individuals targeted, whereas today they are offered permanent or semi-permanent but in principle fully functional small apartments. The apartments, to be sure, are not fully "standard," coming as they do for example without a proper kitchen and a first-hand rental contract. Both before the disciplining staircase model was introduced in the late 1980s, and after it was officially abandoned in 2007 (see Hansen Löfstrand, 2010), homeless persons were - and still are portrayed as suffering from an incurable condition, with the solutions to the homelessness problem based on that premise. The current model for combating homelessness, the Housing First approach, is, however, even where officially adopted, at best embraced at arm's length (Åkerström, 2006). Where it has been put in place and made operative, it (or, rather, some selected aspects of the original model) has been harnessed for the municipality's own, locally defined and determined purposes. As a result, individuals who are long-term homeless continue to be denied any possibility for first-hand apartment contracts. 
Willse (2010, p. 165) has connected the invention of (chronic or long-term) homelessness as a medical problem to the basic notion inspiring the work of modern social service agencies, namely, that it is necessary to "work on yourself" to gain access to and keep an apartment of your own. In this respect, the Housing First model, as already noted, promises to bring a break from the medicalized models by separating shelter provision from health and social services (Willse, 2010, p. 166). Much as a consequence, the reactions to it among social workers, still working on the old assumption that health and social services are necessary for preparing homeless clients for independent living, have been notably reserved. In the city of Gothenburg, too, where some of the model's features have been adopted for use, the approach has been modified to fit locally defined and largely inherited purposes. In line with the original model, the importance of immediate access to permanent housing is emphasized by the municipality, with the result that "the truly homeless" - the homeless regarded as incurably ill - are now being made eligible to it. The housing in question, however, is not regular housing obtained from the rental market that comes with a firsthand rental contract, but instead special housing that is adapted to the perceived special needs of the homeless and comes without standard facilities and standard terms of occupancy. In other words, certain aspects of the Housing First model have been strategically incorporated by adopting them for use for local purposes that, paradoxically enough, are still centered on the framing of long-term homelessness as a medical problem. At the same time, by adhering to the principle of the Housing First model that stresses the need for permanent housing solutions for the homeless while simultaneously defining the problem of homelessness in medical terms, the fact that the goal is no longer to reestablish the homeless in the regular housing market is legitimized. By linking policy shifts to a model perceived as "modern" and "legitimate," the morally questionable strategies of diagnosing homeless people as suffering first and foremost from an incurable condition and of prescribing them permanent special housing in combination with treatment and medical care are camouflaged and thus made less vulnerable to criticism. In effect, then, one might even conclude that the moral legitimacy of the Housing First model is being strategically used for (other) local purposes, to hide from sight what is going on in actual reality: an intensified medicalization of homelessness and a constant narrowing of the category of "the truly homeless." The politics of homelessness manifest in, and in turn propelling, such developments can then but render the pathway out of homelessness even more difficult to traverse. For as long as "the truly homeless" are depicted as suffering from an incurable illness, the problem of homelessness can be "solved" by permanently housing the homeless in special housing units falling short of ordinary standards, with the occupants lacking firsthand rental contracts. Meanwhile, the attention to the structural causes (such as the housing market, housing politics and welfare politics) producing homelessness may comfortably lapse (cf. Conrad, 1992; Lyon-Callo, 2000).

While not ultimately guiding the actions of the decision-makers and high-ranking civil servants in Gothenburg (or in Sweden more broadly), then, where it was used only strategically and selectively for local, pre-existing purposes, we might nevertheless note that the Housing First model with its key objective of promoting access to regular housing with first-hand rental contracts has been fully and successfully implemented elsewhere, for instance in the United States (see Padgett, Gulcur, \& Tsemberis, 2006; Stefancic \& Tsemberis, 2007; Tsemberis et al., 2004), providing a precedent to follow. Furthermore, besides 
prescribing palliative care and medication to homeless clients considered incurably ill (and placing them in long-term or semi-permanent special housing), as was done in Gothenburg, also other measures could have been resorted to that have been offered for consideration as potentially effective means for dealing with mental and physiological problems in this respect. For instance, approaches have been proposed that stress the benefits of extended social networks (the health benefits of good relations with friends, family, partners, and pets), activities for enjoyment and relaxation, nutritious food, and involvement in groupdiscussion programs (Harwood and L'Abate, 2010; L'Abate, 2007b). Through self-initiated and self-administrated self-help where good social relations, enjoyment of life, and general well-being are the goal, it might be possible to promote rehabilitation and self-reliance in this area as well. Such measures to promote good health seem, moreover, to be not just effective but also notably cost-efficient (Harwood \& L'Abate, 2010; L'Abate, 2007a; L'Abate, 2007b). It is hard to see why they could not be considered in the context of the Swedish special-housing provision as well, as a measure to address the mental and physiological problems among the country's homeless population. At the same time, however, one might ask whether the image increasingly promoted of homelessness as an incurable condition with the "truly homeless" depicted as the hopeless cases - might effectively prevent this from happening, at least in the foreseeable future.

\section{References}

Åkerström, M. (2006). Doing Ambivalence: Embracing Policy Innovation - at Arm's Length. Social Problems, Vol.53, No.1, pp. 57-74, ISSN $0037-7791$

City of Gothenburg (2011). Bostad som grund [Housing as a foundation]. Internal working document, City of Gothenburg, Social Resources Department, dated 19.1.2011

Conrad, P. (1992). Medicalization and Social Control. Annual Review of Sociology, Vol.18, pp. 209-232, ISSN 03600572

Conrad, P. \& Schneider, J.W. (1992). Deviance and Medicalization: From Badness to Sickness, Temple University Press, ISBN 13: 978-0-87722-999-5, Philadelphia, USA

Cress, D.M. \& Snow, D.A. (2000). The Outcome of Homeless Mobilization: The Influence of Organization, Disruption, Political Mediation, and Framing. American Journal of Sociology, Vol.105, No.4, pp. 1063-1104, ISSN 0002-9602

Halldin, J. (2000). Avinstitutionaliseringens betydelse för hemlösheten - myter och fakta [The effect of deinstitutionalization on homelessness: Myths and facts], In: Hemlöshet - en antologi om olika perspektiv och förklaringsmodeller [Homelessness: Perspectives and Explanations], W. Runquist \& H. Swärd, (Eds.), 135-148, Carlssons, ISSN 91-7203-977-9, Stockholm, Sweden

Hansen Löfstrand, C. (2010). Reforming the Work to Combat Long-Term Homelessness in Sweden. Acta Sociologica, Vol.53, No.1, pp. 19-34, ISSN 0001-6993

Harwood, M.T. \& L'Abate, L. (2010). Self-Help in Mental Health: A Critical Review. Springer, ISBN 1441910980, New York, USA

Heule, C., Knutagård, M., \& Swärd, H. (2010). Bostad först - ett innovativt försök [Housing First: An innovative approach]. Alkohol \& Narkotika, No.1, pp. 9-12, ISSN 0345-0732 
Holm, P. (n.d.). Uppdrag svårplacerade klienter med utagerande beteende [Assignment: Clients who are difficult to place and have impulsive behavior]. Social Resources Department, City of Gothenburg, Sweden

Ingemarson, M. \& Holmdahl, J. (2010). I lugn och oro. En brukarstudie över Erstabacken, ett medicinskt boende för svårt sjuka hemlösa [In peace and quiet: A study of Erstabacken, a hospice for severely ill homeless persons]. Ersta Sköndal University College, ISSN 1402-277X, Ersta Sköndal, Sweden

Löfstrand, C. (2005). Hemlöshetens politik - local policy och praktik [The Politics of homelessness: Local policy and practice]. Égalité, ISBN 91-975231-4-3, Malmö, Sweden

L'Abate, L. (2007a). Low-Cost Approaches to Promote Physical and Mental Health, In: LowCost Approaches to Promote Physical and Mental Health: Theory, Research, and Practice, L. L'Abate (Ed.), 3-40, Springer, ISBN 0387368981, New York, USA

L'Abate, L. (2007b). Low-Cost Approaches to Promote Physical and Mental Health: Theory, Research, and Practice. Springer, ISBN 0387368981, New York, USA

Loseke, D.R. (2003). Thinking about Social Problems: An Introduction to Constructionist Perspectives (2nd ed.), Aldine de Guyter, ISBN 0-202-30684-4, New York, USA

Lyon-Callo, V. (2000). Medicalizing Homelessness: The Production of Self-Blame and SelfGoverning within Homeless Shelters. Medical Anthropology Quarterly, Vol.14, No.3, pp. 328-345, ISSN 0745-5194

National Board of Health and Welfare (1998). Psykiatrireformen: Årsrapport 1998. Reformens första tusen dagar [Psychiatry reform: Annual report 1998: The first 1,000 days]. Norstedts Juridik, ISBN 91-7201-286-2, Stockholm, Sweden

National Board of Health and Welfare (2006). Hemlöshet $i$ Sverige 2005. Omfattning och karaktär [Homelessness in Sweden, 2005: Scope and nature]. National Board of Health and Welfare, Stockholm, Sweden

Olsson, L.-E. \& Nordfeldt, M. (2008). Homelessness and the Tertiary Welfare System in Sweden: The Role of the Welfare State and Non-profit Sector. European Journal of Homelessness, Vol.2, pp. 157-173, ISSN 2030-3106

Padgett, D.K., Gulcur, L., \& Tsemberis, S. (2006) Housing First Services for People Who Are Homeless with Co-Occurring Serious Mental Illness and Substance Abuse. Research on Social Work Practice, Vol.16, No.1, pp. 74-83, ISSN 1049-7315

Pierson, P. (2000). Increasing Returns, Path Dependence, and the Study of Politics. The American Political Science Review, Vol.94, No.2, pp. 251-267, ISSN 0003-0554

Sahlin, I. (2005). The Staircase of Transition: Survival through Failure. Innovation: The European Journal of Social Science Research, Vol.18, No.2, pp. 115-136, ISSN 1351-1610

Sennemark, E. (2009). Medicinsk kompetens på sociala boenden i Göteborg - behövs det? [Medical competence at social housing units in Gothenburg: Is it needed?]. The Gothenburg Regional Association of Local Authorities (GR), Gothenburg, Sweden

Stefancic, A. \& Tsemberis, S. (2007). Housing First for Long-Term Shelter Dwellers with Psychiatric Disabilities in a Suburban County: A Four-Year Study of Housing Access and Retention. Journal of Primary Prevention, Vol.28, Nos.3-4, pp. 265-279, ISSN 1573-6547 
Tsemberis, S., Gulcur, L., \& Nakae, M. (2004). Housing First, Consumer Choice, and Harm Reduction for Homeless Individuals with a Dual Diagnosis. American Journal of Public Health, Vol.94, No.4, pp. 651-656, ISSN 1541-0048

Willse, C. (2010). Neo-liberal Biopolitics and the Invention of Chronic Homelessness. Economy and Society, Vol.39, No.2, pp. 155-184, ISSN 0308-5147 


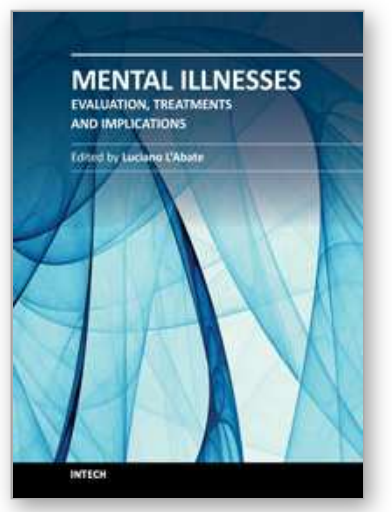

\author{
Mental IIInesses - Evaluation, Treatments and Implications \\ Edited by Prof. Luciano LAbate
}

ISBN 978-953-307-645-4

Hard cover, 476 pages

Publisher InTech

Published online 13, January, 2012

Published in print edition January, 2012

In the book "Mental Illnesses - Evaluation, Treatments and Implications" attention is focused on background factors underlying mental illness. It is crucial that mental illness be evaluated thoroughly if we want to understand its nature, predict its long-term outcome, and treat it with specific rather than generic treatment, such as pharmacotherapy for instance. Additionally, community-wide and cognitive-behavioral approaches need to be combined to decrease the severity of symptoms of mental illness. Unfortunately, those who should profit the most by combination of treatments, often times refuse treatment or show poor adherence to treatment maintenance. Most importantly, what are the implications of the above for the mental health community? Mental illness cannot be treated with one single form of treatment. Combined individual, community, and socially-oriented treatments, including recent distance-writing technologies will hopefully allow a more integrated approach to decrease mental illness world-wide.

\title{
How to reference
}

In order to correctly reference this scholarly work, feel free to copy and paste the following:

Cecilia Hansen Löfstrand (2012). Homelessness as an Incurable Condition? The Medicalization of the Homeless in the Swedish Special Housing Provision, Mental Illnesses - Evaluation, Treatments and Implications, Prof. Luciano LAbate (Ed.), ISBN: 978-953-307-645-4, InTech, Available from: http://www.intechopen.com/books/mental-illnesses-evaluation-treatments-and-implications/homelessness-asan-incurable-condition-the-medicalization-of-the-homeless-in-the-swedish-special-hou

\section{INTECH}

open science | open minds

\section{InTech Europe}

University Campus STeP Ri

Slavka Krautzeka 83/A

51000 Rijeka, Croatia

Phone: +385 (51) 770447

Fax: +385 (51) 686166

www.intechopen.com

\section{InTech China}

Unit 405, Office Block, Hotel Equatorial Shanghai

No.65, Yan An Road (West), Shanghai, 200040, China

中国上海市延安西路65号上海国际贵都大饭店办公楼 405 单元

Phone: +86-21-62489820

Fax: $+86-21-62489821$ 
(C) 2012 The Author(s). Licensee IntechOpen. This is an open access article distributed under the terms of the Creative Commons Attribution 3.0 License, which permits unrestricted use, distribution, and reproduction in any medium, provided the original work is properly cited. 